\title{
KEJADIAN GANGGUAN MENSTRUASI BERDASARKAN STATUS GIZI PADA REMAJA
}

\author{
Mira Miraturrofi'ah ${ }^{1}$ \\ 1) Program Studi DIII Kebidanan - Institut Kesehatan Rajawali \\ mirrawahab18@gmail.com
}

\begin{abstract}
ABSTRAK
Gangguan menstruasi masih menjadi masalah yang sering ditemukan dengan angka kejadian cukup tinggi terutama pada remaja. Sebanyak 75\% remaja mengalami gangguan terkait dengan menstruasi Kondisi tersebut diperparah dengan pola makan remaja yang belum baik, yang berakibat pada peningkatan status gizi yang tidak normal. Apabila tidak dikelola dengan baik, kondisi tersebut dapat memengaruhi kualitas, produktivitas dan aktivitas remaja sehari-hari. Tujuan penelitian ini adalah untuk mengetahui kejadian gangguan menstruasi berdasarkan status gizi pada siswi remaja YPPS Bandung. Jenis dan rancangan yang digunakan adalah metode penelitian deskriptif, menggunakan pendekatan cross sectional study. Populasi adalah siswi remaja usia 10-19 tahun dengan jumlah sampel dengan menggunakan teknik total sampling adalah 102 orang. Instrumen penelitian yang digunakan adalah kuesioner gangguan menstruasi dan timbangan berat badan serta pengukur tinggi badan. Angka kejadian status gizi kurus sebesar 23,52\%, normal 35,29\%, gemuk 41,17\%. Simpulan dari penelitian ini adalah gangguan menstruasi banyak dialami oleh remaja dengan status gizi lebih yaitu sebesar 91,17\%. Adapun jenis dari gangguan menstruasi yang banyak dialami oleh siswi remaja disana adalah hipermenorea.
\end{abstract}

Kata kunci : gangguan menstruasi, remaja, status gizi

\begin{abstract}
Menstrual disorders are still a problem that often found with a reasonably high incidence, especially in adolescents. As many as $75 \%$ of teenagers experience with menstrual disorders. The condition is exacerbated by adolescent eating habits that have not been good, which abnormal nutritional status. If not managed properly, these conditions can affect the quality, productivity and daily activities of adolescents. The purpose of this study was to determine the incidence of menstrual disorders based on nutritional status in YPPS Bandung teenage girls. The type and design used is a descriptive research method, using a cross-sectional study approach. The population is teenage girls aged 10-19 years, with a total sample of 102 people. The research instrument used was a questionnaire of menstrual disorders and weight scales and height measurements. The results showed the incidence of underweight nutrition by $23.52 \%$, standard $35.29 \%$, fat $41,17 \%$. The conclusion from this study is that menstrual disorders experienced by many adolescents with over nutritional status that is equal to $91.17 \%$. The type of menstrual disorders experienced by many teenage girls there is hypermenorrhoea..
\end{abstract}

Keywords: adolescent, menstrual disorders, nutritional status 


\section{PENDAHULUAN}

Remaja atau "adolescence" (Inggris), berasal dari bahasa latin "adolescere" yang berarti tumbuh ke arah kematangan. Kematangan yang dimaksud adalah bukan hanya kematangan fisik saja, tetapi juga kematangan sosial dan psikologis. Batasan usia remaja menurut WHO adalah 12-24 tahun, sedangkan menurut Kemenkes RI adalah antara 10 - 19 tahun dan belum kawin (Pusdatin, 2017). Adapun dari aspek program pelayanan, fase remaja merupakan periode yang paling rawan dalam perkembangan hidup manusia setelah ia mampu bertahan hidup (survive), yang mana secara fisik ia akan mengalami perubahan yang spesifik dan secara psikologi cenderung mencari identitas diri.

Memasuki usia remaja atau pubertas, beberapa jenis hormon, terutama hormon estrogen dan progesteron mulai berperan aktif sehingga organ-organ reproduksi mulai berfungsi. Terjadinya kematangan seksual atau alat-alat reproduksi yang berkaitan dengan sistem reproduksi merupakan suatu bagian penting dalam kehidupan remaja sehingga diperlukan perhatian khusus, agar dapat tertangani secara tuntas. Beberapa ciri masa pubertas pada perempuan adalah mulai terjadinya menstruasi, mulai tumbuh payudara, pinggul melebar dan membesar. Terjadinya perubahan besar ini umumnya membingungkan remaja yang mengalaminya (Batubara, 2016).

Salah satu ciri masa pubertas pada perempuan adalah mulai terjadinya menstruasi. Dimana menstruasi merupakan keluarnya darah dan jaringan dari lapisan rahim dalam setiap bulannya (Yusiana et al., n.d.)3\%. Usia ratarata menarche adalah 12,9 tahun. Adapun durasi periode menstruasi, hal ini dianggap normal apabila berada dalam variasi antara 2 hingga 7 hari (rata-rata 4 hari). Di sisi lain, interval normal antara setiap periode adalah antara 21 hingga 35 hari (kebanyakan adalah 26-30 hari), hal ini sangat tergantung pada fase folikular. Selanjutnya, pengeluaran darah selama menstruasi yang mungkin paling sulit untuk menilai mengacu pada jumlah perdarahan saat menstruasi. Secara umum, total volume normal tidak boleh $>80 \mathrm{ml}$ (rata-rata 30-40 $\mathrm{mL}$ per siklus).

Dalam perjalanannya, tidak semua remaja yang mengalami menstruasi akan berjalan dengan lancar tanpa keluhan. Tahun-tahun awal menstruasi merupakan periode yang rentan terhadap terjadinya gangguan menstruasi (Lubis et al., 2017). Tujuh puluh lima persen wanita pada tahap remaja akhir mengalami gangguan yang terkait dengan menstruasi. Banyak dari wanita yang mengalami gangguan menstruasi saat masa menstruasinya. Gangguan menstruasi meliputi ketidakteraturan siklus menstruasi (durasi atau panjang), hiper-atau hypomenorrhoe, poliatau oligomenorea, dismenorea, amenorea, dan sindrom pramenstruasi (Karout et al., 2012) Lebanon. Of 352 students completing a written questionnaire, the most common menstrual disorders were irregular frequency ofmenstruation (80.7\%. Dalam suatu penelitian yang dilakukan oleh M Cakir dkk pada Mahasiswi di Turki tahun 2007 ditemukan bahwa dismenorea merupakan ganguan menstruasi dengan prevalensi terbesar $(89,5 \%)$, diikuti ketidakteraturan menstruasi $(31,2 \%)$, serta perpanjangan durasi menstruasi $(5,3 \%)$. Pada pengkajian terhadap penelitianpenelitian lain didapatkan prevalensi tertinggi pada remaja. Mengenai gangguan lainnya, Bieniasz J dkk mendapatkan prevalensi amenorea primer sebanyak 5,3\%, amenorea sekunder $18,4 \%$, oligomenorea $50 \%$, polimenorea $10,5 \%$, dan gangguan campuran sebanyak 15,8\%. Diperkirakan hampir 90\% wanita di Amerika Serikat mengalami dismenorea, $10-15 \%$ diantaranya termasuk dalam dismenorea berat (Lubis et al., 2017).

Penelitian yang dilakukan oleh Fakultas Kedokteran Universitas Indonesia di SMA X 
menemukan, 63,2\% responden mengalami gangguan menstruasi. Sedangkan data yang didapatkan dari RISKESDAS tahun 2010 diketahui bahwa sekitar 15,8 \% remaja tingkat SMP mengalami gangguan ketidakteraturan siklus menstruasi. Sedangkan untuk remaja tingakat SMA gangguan ketidak teraturan menstruasi mencapai 15,7 \% (Kementrian Kesehatan RI, 2010). Data lain menunjukan, angka kejadian dismenorhea di Indonesia mencapai $64.25 \%$. Banyak faktor yang dapat menyebabkan terjadinya gangguan menstruasi salah satunya adalah status gizi (Lubis et al., 2017). Sebuah penelitian yang dilakukan pada tahun 2018 menemukan bahwa indeks antropometri berhubungan dengan gangguan menstruasi pada wanita. Dalam penelitian tersebut juga di temukan adanya hubungan yang bermakna antara IMT dengan terjadinya gangguan menstruasi (Rad et al., 2018).

Status gizi merupakan keadaan kesehatan tubuh seseorang atau sekelompok orang yang diakibatkan oleh konsumsi, penyerapan (absorbsi), dan penggunaan (utilization) zat gizi makanan. Status gizi seseorang tersebut dapat diukur dan dinilai. Banyak cara yang dapat dilakukan untuk mengukur stastus gizi seseorang, salah satunya adalah melalui pengukuran indeks masa tubuh (IMT).

Melihat pola makan remaja saat ini yang sangat memprihatinkan, banyak dari remaja yang dapat dikatakan belum berpola makan sehat. Seperti masih rendahnya sarapan pada remaja. Sebuah data menunjukkan bahwa, masih banyak siswa sekolah yang melewatkan sarapan sehat, yaitu sekitar 35000 anak usia sekolah (26.1\%) hanya sarapan dengan air minum, 44.6\% asupan energi dari sarapan kurang dari 15\% AKG energi (Sari et al., 2016)Bogor District. Breakfast consumption was collected by a 7-day food records. The result showed that there were $45.6 \%$ schoolgirls having breakfast regularly. Breakfast frequency per week was associated with BMI and anaemic status (p\&lt;0.05. Melewatkan waktu makan dapat berpengaruh terhadap penurunan konsumsi energi, protein dan zat gizi lain. Selain itu ketersediaan makanan cepat saji serta promosi makanan instan yang kebanyakan lebih mengutamakan rasa dibandingkan dengan kandungan gizi di dalamnya, membuat remaja lebih menyukai makanan tersebut dibandingkan dengan makanan yang dibuat di rumah sehingga apabila kondisi tersebut terjadi dalam jangka waktu yang lama dapat memperburuk status gizi dari remaja itu sendiri.

Data yang didapatkan dari RISKESDAS 2018 menunjukan sebanyak $24.7 \%$ remaja usia 13 - 15 tahun mengalami gangguan status gizi dengan rincian sebagai berikut : sangat kurus $1.9 \%$, kurus $6.8 \%$, gemuk $11,2 \%$, dan obesitas $4.8 \%$. Sementara itu gangguan status gizi pada remaja usia 16 - 18 tahun sebesar $21.6 \%$ dengan rincian sebagai berikut : sangat kurus $1.4 \%$, kurus $6.7 \%$, gemuk $9.5 \%$, dan obesitas $4.0 \%$ (Badan Litbang Kesehatan, 2018). Kondisi ini mungkin akan sangat berbeda dengan status gizi pada siswi remaja YPPS Bandung. Dimana dari study pendahuluan yang telah dilakukan, diketahui bahwa, hampir seluruh remaja siswi di YPPS Bandung ini diwajibkan untuk tinggal di asrama, kegiatan pembelajaran yang sangat padat yaitu delapan jam di lingkungan sekolah dan 5-6 jam dilingkungan pesantren yang bagi sebagian siswi remaja kemungkinan besar dapat melewatkan makan utamanya sehingga makanan pengganti dalam bentuk jajanan dan snack dengan kandungan gizi yang belum tentu dapat memenuhi kebutuhan tubuh akan ditempuh sebagai pengganti makan utamanya. Dengan pola makan tersebut, siswi remaja tidak akan dapat mencukupi kebutuhan energi yang telah digunakan dalam kegiatan pembelajaran yang sangat padat serta aktifitas kegiatan lainnya. Selain itu, dari study pendahuluan yang 
telah dilakukan diketahui bahwa, gangguan menstruasi merupakan masalah yang sering ditemukan dengan prevalensi terbanyak pada kelompok remaja. Dimana dari survei awal yang dilakukan terhadap 43 remaja yang telah mengalami menstruasi, ditemukan sebanyak 95,35\% remaja mengalami gangguan menstruasi. Dimana, seorang remaja dapat mengalami beberapa macam gangguan menstruasi. Gangguan menstruasi yang dialami meliputi: polymenorhea oligomenorrhea, hypomenorrhea, hypermenorrhea, dysmenorrhea. Berdasarkan hasil studi pendahuluan diatas, dapat dilihat bahwa angka kejadian gangguan menstruasi pada siswi remaja YPPS Bandung masih sangat tinggi. Apabila tidak ditangani, gangguan menstruasi dapat mempengaruhi kualitas hidup dan aktivitas sehari-hari.

Atas latar belakang itulah, peneliti tertarik untuk melakukan penelitian dengan judul "Kejadian Gangguan Menstruasi Berdasarkan Status Gizi Pada Remaja”. Melalui penelitian ini, diharapkan dapat mengidentifikasi kejadian gangguan menstruasi di YPPS, serta bagaimana pengaruh status gizi dalam menyebabkan gangguan tersebut. Dengan mengetahui hal tersebut, upaya perbaikan serta pencegahan dapat dilakukan untuk mengurangi angka kejadian gangguan menstruasi pada remaja.

\section{METODOLOGI}

Metode penelitian yang digunakan dalam penelitian ini adalah metode deskriptif observasional dengan pendekatan cross sectional study, data yang digunakan diperoleh dari kuisioner dan pemeriksaan (BB+TB) subjek yang dilakukan satu kali selama penelitian.

Populasi dalam penelitian ini adalah seluruh siswi remaja yang telah mengalami menstruasi di YPPS Bandung. Teknik pengambilan sampel dalam penelitian ini adalah total sampling. Total sampling adalah teknik pengambilan sampel dimana jumlah sampel sama dengan populasi. Dengan begitu, jumlah sampel dalam penelitian ini adalah seluruh siswi remaja sebanyak 102 orang. Kriteria inklusi dalam penelitian ini adalah : siswi remaja yang telah berusia 10-19 tahun, sudah menstruasi minimal 2 tahun yang lalu saat dilakukannya pengambilan data, tidak sedang dalam pengobatan hormonal (termasuk kontrasepsi) ataupun sedang mengidap penyakit berat.

Data yang digunakan adalah data pimer yaitu kuesioner untuk menilai ada tidaknya gangguan menstruasi, serta pemeriksaan antopometri (BB dan TB) untuk menilai IMT.. Pengolahan data dilakukan melalui tahapan seleksi data, pemberian kode dan skoring. Data kemudian di input kedalam perangkat lunak SPSS untuk dilakukan analisis data.

\section{HASIL}

Tabel 1. Distribusi Frekuensi Siswi Berdasarkan Status Gizi

\begin{tabular}{lcc}
\hline Status Gizi & f & \% \\
\hline Kurang & 24 & 23,52 \\
Normal & 36 & 35,29 \\
Lebih & 42 & 41,17 \\
\hline Jumlah & $\mathbf{1 0 2}$ & $\mathbf{1 0 0}$ \\
\hline
\end{tabular}

Tabel 2. Distribusi Frekuensi Siswi

Berdasarkan Gangguan Menstruasi

\begin{tabular}{lcc}
\hline Variabel & f & $\mathbf{\%}$ \\
\hline $\begin{array}{l}\text { Tidak mengalami } \\
\text { gangguan menstruasi }\end{array}$ & 9 & 8,83 \\
$\begin{array}{l}\text { Mengalami gangguan } \\
\text { menstruasi }\end{array}$ & 93 & 91,17 \\
\hline Jumlah & $\mathbf{1 0 2}$ & $\mathbf{1 0 0}$ \\
\hline
\end{tabular}


Tabel 3. Gangguan Menstruasi Berdasarkan Status Gizi

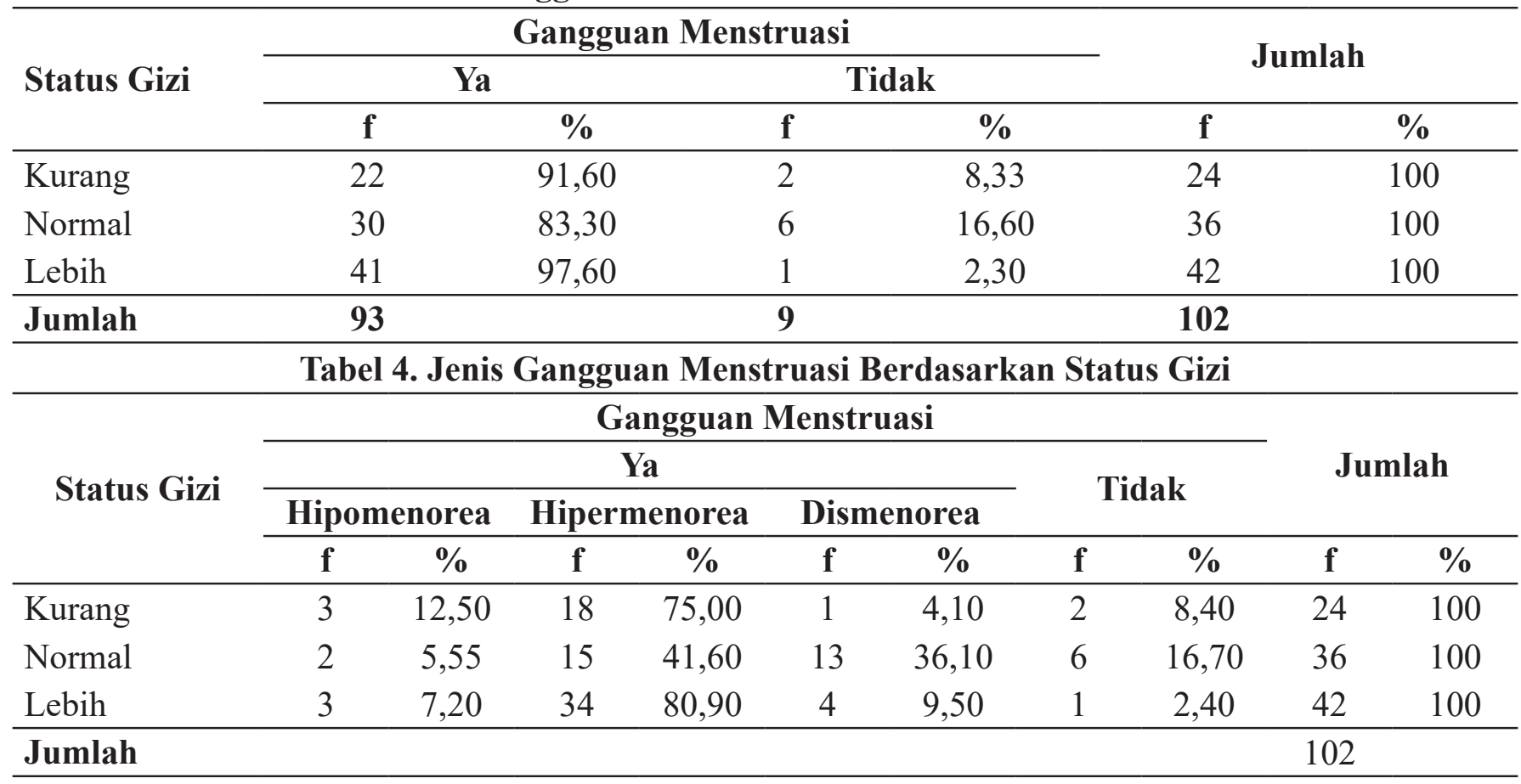

\section{PEMBAHASAN}

1. Distribusi Frekuensi Siswi Berdasarkan Status Gizi

Pada tabel 1 dijelaskan mengenai gambaran status gizi siswi remaja YPPS. Dari tabel tersebut diketahui bahwa dari 102 siswi hanya 36 siswi $(35,29 \%)$ mempunyai status gizi normal, selanjutnya untuk status gizi kurang dan lebih masing-masing 23,52\% dan 41,17\%. Hasil ini berbeda dengan penelitian yang dilakukan oleh Derina pada tahun 2011, dimana dalam penelitiannya didapatkan bahwa dari 102 siswi remaja, sebanyak 73 siswi ada dalam status gizi normal (Derina, 2011).

Banyak kemungkinan yang dapat menyebabkan tingginya angka status gizi tidak normal pada siswi YPPS ini. Salah satunya mungkin dikarenakan kegiatan pembelajaran yang sangat padat yaitu delapan jam di lingkungan sekolah kemudian dilanjutkan 5-6 jam dilingkungan pesantren yang bagi sebagian siswi remaja kemungkinan besar dapat melewatkan makan utamanya. Sehingga makanan pengganti dalam bentuk jajanan dan snack dengan kandungan gizi yang belum tentu dapat memenuhi kebutuhan tubuh akan ditempuh sebagai pengganti makan utamanya. Dengan pola makan tersebut, memungkinkan tidak tercukupinya zat-zat nutrisi tertentu yang kemudian berpengaruh terhadap kondisi status gizi remaja. Selain itu, bukan hal yang mustahil apabila kesibukan remaja dengan berbagai aktifitasnya serta kurangnya informasi mengenai makanan sehat menyebabkan remaja cenderung memiliki pola makan yang kurang baik yang berdampak negatif pula pada status gizi nya.

Kebutuhan gizi remaja sendiri relatif besar, karena masih mengalami masa pertumbuhan. Selain itu, aktivitas fisik yang umumnya lebih tinggi dibanding usia lainnya, menyebabkan remaja memerlukan zat gizi yang lebih banyak. Widyakarya Nasional Pangan Gizi VI (WKNPG VI) menyarankan angka kecukupan gizi (AKG) energi untuk remaja dan dewasa muda perempuan 2000-2200 kkal. AKG energi ini 
dianjurkan sekitar $60 \%$ berasal dari sumber karbohidrat misal : beras, terigu beserta hasil olahannya (mie, spagetti, makaroni), umbi-umbian (ubi jalar, singkong), jagung, gula dan lain-lain. AKG protein pada remaja dan dewasa muda perempuan adalah 48-62 gr per hari, sedangkan AKG untuk kalsium pada remaja dan dewasa muda perempuan adalah 600-700 mg per hari. Selain itu pada masa remaja juga membutuhkan kadar seng (zink). Dimana seng (zink) itu diperlukan untuk pertumbuhan serta kematangan seksual remaja, terutama untuk remaja lakilaki. AKG seng adalah $15 \mathrm{mg}$ per hari untuk remaja dan dewasa muda perempuan dan lakilaki. Kebutuhan zat besi pada remaja juga meningkat karena terjadinya pertumbuhan cepat. Pada perempuan kebutuhan yang tinggi akan zat besi terutama disebabkan kehilangan zat besi selama menstruasi. Hal ini mengakibatkan perempuan lebih rawan terhadap anemia akibat defisiensi zat besi dibandingkan laki-laki (Atikah Proverawati, 2010).

2. Distribusi Frekuensi Siswi Berdasarkan Gangguan Menstruasi.

Berdasarkan Tabel 2 diketahui bahwa, prevalensi gangguan menstruasi terjadi pada $93,13 \%$ dari 102 . Tingginya angka kejadian gangguan menstruasi di kalangan remaja ini sejalan dengan penelitian yang dilakukan oleh S.Milla dkk, dimana dalam penelitian nya ditemukan hasil lebih dari 90\% responden remaja mengalami gangguan menstruasi (Milla et al., 2018). Sementara itu, berdasarkan Chung PW dkk di Pediatric and Adolescent Gynaecology Clinic (PAGC), angka kejadian gangguan menstruasi terjadi pada 69\% remaja. Perbedaan hasil ini dimungkinkan karena adanya perbedaan jumlah sampel dan karakteristik sampel serta metode penelitian yang digunakan.
Dalam penelitian yang dilakukan di YPPS ini, sampel yang dilibatkan hanya 102 orang yang mana merupakan siswi remaja yang berusia 11-19 tahun yang telah memenuhi kriteria yang telah ditetapkan. Sementara penelitian yang dilakukan oleh Chung dkk, menggunakan metode penelitian Prospective Cohort Study dengan pengambilan sampel jauh lebih besar yaitu 1014 serta didukung oleh tenaga ahli yang mahir dibidangnya. Dengan begitu, didapatkan pula out put yang bervariasi dalam masing-masing hasil yang didapatkan (Chung et al., 2011). Walau begitu, dapat disimpulkan bahwa gangguan menstruasi pada remaja terjadi pada lebih dari setengah dari keseluruhan jumlah sampel yang dilibatkan. Ini menunjukan bahwa angka kejadian gangguan menstruasi masih sangat tinggi, dan masih perlu banyak hal yang dilakukan untuk mengatasi permasalahan ini.

Melihat usia responden yang kebanyakanadapadarentangusia 13-15 tahun, ada kemungkinan faktor tersebut menjadi penyebab tingginya kejadian gangguan menstruasi di YPPS ini. Hal ini disebabkan karena pada rentang usia tersebut, koordinasi antara hipotalamus, hipofise, hormonal dan organ-organ pendukung lainnya belum sepenuhnya berfungsi dengan maksimal. Sehingga adalah hal yang wajar apabila terdapat ketidak seimbangan yang pada akhirnya menyebabkan tingginya kejadian gangguan menstruasi pada siswi remaja disana. Keadaan menstruasi yang tidak teratur pada masa 3-5 tahun setelah menarche dan pramenopause (sekitar 3-5 tahun menjelang menopause) merupakan keadaan yang lazim dijumpai (Lubis et al., 2017). Selain itu, Shadia dalam penelitiannya mengemukakan bahwa, dibutuhkan waktu kurang lebih dua tahun dari usia menarche bagi seorang 
remaja putri untuk mendapatkan siklus yang teratur dan stabil. Karena pada siklus-siklus awal, ada kemungkinan menstruasi remaja putri tersebut hanya bersifat anovulatoar (tidak adanya ovulasi). Selain itu, gangguan menstruasi juga dapat disebabkan oleh faktor-faktor lainnya. Faktor-faktor tersebut seperti aktifitas, genetik, tingkat stress yang tinggi, adanya penyakit dan adanya status gizi yang tidak normal (underweight atau overweight) (Mahitala, 2015).

\section{Kejadian Gangguan Menstruasi Berdasarkan Status Gizi}

Berdasarkan tabel 3 diketahui bahwa gangguan menstruasi banyak terjadi pada remaja dengan status gizi lebih, yaitu dari 42 siswi sebanyak 41 orang $(97,6 \%)$. Setelah itu gangguan menstruasi ditemukan juga pada remaja yang mempunyai status gizi kurang, yaitu sebesar 91,6\%. Untuk siswi dengan status gizi normal, hanya sebesar $83,3 \%$ dari 36 siswi yang mengalami gangguan menstruasi. Hal ini serupa dengan penelitian yang dilakukan oleh Sianipar dkk, dimana dalam penelitiannya mereka menemukan bahwa gangguan menstruasi cenderung banyak dialami oleh remaja yang memiliki IMT yang cenderung tinggi (Sianipar et al., 2009). Selain itu Harlow dkk dan Rowland dkk juga mendapatkan hubungan bermakna antara tingginya IMT dan perpanjangan siklus menstruasi. Gangguan menstruasi juga dapat terjadi pada wanita yang memiliki IMT rendah, seperti yang didapatkan oleh Hirata dkk, mereka menemukan bahwa terdapat peningkatan risiko pada wanita yang mempunyai IMT rendah untuk mengalami nyeri saat menstruasi. Hal tersebut menunjukkan bahwa jenis gangguan menstruasi yang terjadi bergantung pada nilai IMT (underweight atau overweight).

Terkait dengan gangguan menstruasi, hal mendasar yang perlu dipahami adalah bahwa gangguan menstruasi pada dasarnya berhubungan erat dengan adanya gangguan hormon terutama yang berhubungan dengan hormon seksual pada perempuan yaitu Progesteron, Estrogen, LH dan FSH.

Hormon-hormon seksual tersebut sangat berfungsi pada sistem reproduksi perempuan. Namun pada beberapa kondisi terjadi peningkatan salah satu saja yang mana hal tersebutmenunjukkan ketidakseimbangan sintesis hormon dalam tubuh dan hal ini dapat mempengaruhi fungsi kerja hormon lain termasuk kinerja organ reproduksi yang mempengaruhi rangsangan terjadinya gangguan menstruasi. Banyak kemungkinan yang dapat mempengaruhi terjadinya ketidakseimbangan sintesis hormon yang pada akhirnya akan mempengaruhi kinerja pada tubuh (salah satunya kinerja dalam siklus bulanan). Faktor-faktor tersebut seperti aktifitas, genetik, tingkat stress yang tinggi, adanya penyakit dan adanya status gizi yang tidak normal (underweight atau overweight) (Mahitala, 2015).

Adanya gangguan dari kerja sistem hormonal (menstruasi) terkait dengan status gizi akan mempengaruhi kerja berupa peningkatan, keseimbangan ataupun penurunan. Status gizi sendiri pada dasarnya dipengaruhi oleh banyak faktor, namun secara umum dipengaruhi oleh adanya infeksi dan kualitas dan kuantitas asupan makan. Pola makan yang tidak seimbang akan mempengaruhi penurunan dan peningkatan status gizi. Kondisi ini akan sangat rentan terutama di kalangan remaja. Banyak remaja yang belum berpola makan sehat, seperti masih rendahnya sarapan pada remaja. Melewatkan waktu makan dapat menyebabkan penurunan konsumsi energi, protein dan zat gizi lain. Selain 
itu, ketersediaan makanan cepat saji serta promosi makanan instan yang kebanyakan lebih mengutamakan rasa dibandingkan dengan kandungan gizi di dalamnya, membuat remaja lebih menyukai makanan tersebut dibandingkan dengan makanan yang dibuat di rumah sehingga apabila kondisi tersebut terjadi dalam jangka waktu yang lama dapat memperburuk status gizi dari remaja itu sendiri.

Siswi remaja dengan status gizi lebih tentunya dapat meningkatkan kerja organorgan tubuh sebagai bentuk kemampuan tubuh untuk menetralisir pada keadaan semula dalam rangka pengeluaran kelebihan tersebut. Hal ini tentunya dapat berdampak pada fungsi sistem hormonal tubuh baik berupa peningkatan maupun penurunan kadar progesteron, estrogen, LH (Luetezing Hormon), dan FSH (Folikel Stimulating Hormon) yang dapat menyebabkan terganggunya proses koordinasi sistem organ reproduksi dan hormon reproduksi tersebut sehingga menimbulkan kemungkinan gangguan menstruasi (Lubis et al., 2017).

Mereka dengan status gizi lebih kemungkinan menerapkan pola makan berlebih terutama lemak, protein dan karbohidrat tubuh sebagai sumber energi utama tubuh. Seperti yang didapatkan dari penelitian yang telah dilakukan, dari 102 siswi yang dijadikan sampel, sebanyak 42 siswi $(41,17 \%)$ mengalami status gizi lebih. Siswa dengan status gizi gemuk memiliki risiko tertinggi mengalami siklus panjang dan ketidakteraturan dalam siklus menstruasi.

Sementara itu, faktor kurangnya nutrisi pada seseorang dapat berdampak pada penurunan fungsi reproduksi. Hal ini dapat diketahui apabila seseorang mengalami perubahan-perubahan hormon tertentu yang ditandai dengan adanya penurunan berat badan yang mencolok (Kurus IMT $<18,5)$. Keadaan ini terjadi karena kadar gonadotropin dalam serum dan urine menurun serta penurunan pola sekresinya, kejadian tersebut berhubungan dengan gangguan fungsi hipotalamus. Jika kadar gonadotropin menurun maka sekresi FSH serta hormon estrogen dan progesteron juga mengalami penurunan, sehingga tidak menghasilkan sel telur matang yang dapat berdampak pada munculnya gangguan siklus haid. (Lubis et al., 2017). Pada kalangan remaja, status gizi kurang yang mampu menyebabkan terjadinya gangguan menstruasi dapat dipicu oleh pengaruh lingkungan terutama teman sebaya. Banyak dari remaja yang sangat memikirkan perihal penampilan tubuh. Takut akan tubuhnya tidak ideal sering kali menjadikan remaja mengatur pola makan sesuka hatinya sehingga dilakukan usaha keras agar mendapatkan tubuh yang menurutnya ideal namun abnormal secara kesehatan karena zat-zat yang dibutuhkan oleh tubuh tidak terpenuhi. Salah satunya dilakukan dengan cara diet ekstrim yang dapat menyebabkan penurunan IMT yang dapat memicu kemungkinan terjadinya gangguan menstruasi. Sebuah penelitian dilakukan untuk mengetahui pengaruh diet vegetarian terhadap hormon seks wanita, 9 orang vegetarian diberi diet yang mengandung daging, ternyata fase folekuler memanjang, rata-rata 4.2 hari juga $\mathrm{FSH}$ meningkat, $\mathrm{E}_{2}$ menurun secara signifikan. Sebaliknya 16 orang diet biasa beralih ke diet yang kurang daging selama dua bulan mengalami pemendekan fase folikuler, rata-rata 3.8 hari, mengalami penurunan frekuensi puncak LH dan peningkatan kadar LH. Setelah mengalami dua kali injeksi, terjadi hubungan antara diet dengan fungsi menstruasi. Pada wanita yang mengkonsumsi diet vegetarian 
terjadi peningkatan frekuansi gangguan siklus menstruasi. Prevalensi ketidakteraturan menstruasi $26.5 \%$ pada vegetarian dan $4.9 \%$ pada nonvegetarian. Sedangkan pada diet rendah lemak akan menyebabkan tiga efek utama, yaitu pemanjangan siklus menstruasi meningkat rata-rata 1.3 hari, lamanya waktu menstruasi meningkat rata-rata 0.5 hari, dan fase folekuler meningkat rata-rata 0.9 hari. Dengan demikian maka bagi wanita yang bukan vegetarian bila berubah ke diet rendah lemak akan memperpanjang siklus menstruasi sebagai akibat dari memanjangnya fase menstruasi dan fase folikuler. Komposisi diet baik secara kuantitatif maupun kualitatif, dianggap mempengaruhi menstruasi dan penampilan reproduksi. Ada banyak kontroversi hipotesis tentang efek konsumsi asupan serat pada pemeliharaan fungsi reproduksi. Lloyd menjelaskan bahwa asupan tinggi serat makanan dapat mengakibatkan ketidakteraturan dalam penyimpangan siklus menstruasi karena peningkatan ekskresi estrogen dengan kotoran. Dalam penelitian yang dipresentasikan oleh Christo dkk. pernyataan ini tidak dikonfirmasi (Lagowska et al., 2010).

4. Jenis Gangguan Menstruasi Berdasarkan Status Gizi

Dari tabel 4 diketahui bahwa, jenis gangguan menstruasi yang banyak dialami oleh remaja baik pada status gizi kurang, normal, dan lebih adalah gangguan hipermenorea, yaitu sebesar $75 \%$ pada status gizi kurang, 41,6\% pada status gizi normal, dan $80,9 \%$ kejadian hipermenorea pada status gizi lebih. Temuan ini serupa dengan penelitian yang dilakukan oleh Chung dkk yang menemukan bahwa hipermenorea merupakan gangguan menstruasi dengan angka kejadian yang tinggi yaitu sebesar $56 \%$ dari 124 sampel penelitian yang digunakan
(Chung et al., 2011).

Hipermenorea sendiri didefinisikan sebagai suatu kondisi apabila durasi periode atau lamanya mentruasi $>7$ hari dan kehilangan darah $>80 \mathrm{~mL}$ (menggunakan $\geq 5$ pembalut). Meski tidak menyebabkan tinggi nya motalitas, kondisi ini dapat menyebabkan terganggunya kualitas hidup seorang remaja baik dari segi fisik, mental, sosial, maupun material. Banyaknya pengeluaran darah yang terjadi dapat menyebabkan tingginya kemungkinan anemia pada remaja. Banyak faktor yang dapat menyebabkan terjadinya hypermenorrhea, kemungkinan hipermenorea dapat disebabkan karena adanya mioma uteri, polip endometrium atau hyperplasia endometrium (penebalan dinding rahim) (Karout et al., 2012). Dalam kaitannya dengan status gizi, hiperplasia dinding endometrium dapat diakibatkan oleh tingginnya kadar hormon reproduksi utamanya kadar progesteron yang mana ini dapat terjadi akibat tidak normalnya status gizi seseorang. Meskipun demikian, mengingat banyaknya faktor yang dapat menyebabkan hipermenorea dan terbatasnya variabel dalam penelitian di YPPS ini (hanya mengkaitkan dengan status gizi), diperlukan penelitian lebih lanjut dengan melibatkan faktor etiologi hipermenorea lain, sehingga dapat ditemukan penyebab lebih pasti terjadinya gangguan menstruasi hipermenorea pada remaja di YPPS.

Berdasarkan tabel 4 juga dapat diketahui bahwa gangguan hipomenorea dan dismenorea terlihat lebih rendah pada setiap kategori remaja berdasarkan status gizi. Pada remaja dengan status gizi kurang angka kejadian hipomenorea lebih tinggi jika dibandingkan dengan angka kejadian dismenorea. Sedangkan pada remaja dengan status gizi lebih kejadian hipomenorea justru 
lebih rendah jika dibandingkan dengan gangguan dismenorea.

Hipermenorea merupakan keadaan durasi haid yang lebih pendek dan atau jumlah darah haid yang sedikit. Hipomenore terjadi karena endometrium tidak tumbuh optimal. Beberapa keadaan yang dapat menyebabkan hipomenorea, antara lain gangguan hormonal yang menyebabkan penekanan produksi estrogen yang kemudian menyebabkan kurangnya penebalan pada dinding endometrium yang akhirnya menyebabkan volume darah menstruasi lebih sedikit atau lama haid lebih pendek.

Dismenorea merupakan kondisi dimana adanya rasa nyeri saat menstruasi. Rasa nyeri ini terutama dirasakan pada perut bagian bawah dan punggung serta biasanya terasa seperti kram. Dismenorea dibagi menjadi dua, yaitu dismenorea primer dan dismenorea sekunder. Berkaitan dengan status gizi, ketidakseimbangan status gizi pada remaja dapat menyebabkan ketidak seimbangan pada hormon reproduksi (estrogen dan progesterone) juga sekresi hormon prostaglandin dapat meningkat sehingga meningkatkan amplitude dan frekuensi kontraksi uterus dan menyebabkan vasospasme arteriol uterus, sehingga mengakibatkan iskemi dan kram pada abdomen bawah yang bersifat siklik (Lubis et al., 2017). Dalam sebuah penelitian di temukan bahwa, selain status gizi dismenorea juga dapat di sebabkan oleh faktor lain yang tidak di teliti pada penelitian di YPPS ini yaitu, usia, status menikah dan belum menikah (terkait dengan koitus) serta genetik (Novia et al., n.d.). Larasati dan Alatas dalam penelitiannya menemukan bahwa selain IMT yang tidak normal, faktor risiko yang sering berkaitan dengan dismenore yaitu menarke usia dini, riwayat keluarga dengan keluhan dismenore, kebiasaan memakan makanan cepat saji, durasi perdarahan saat haid, terpapar asap rokok, konsumsi kopi dan alexythimia (Larasati \& Alatas, 2016).

\section{SIMPULAN DAN SARAN}

\section{Simpulan}

Berdasarkan penelitian dengan judul "Kejadian Gangguan Menstruasi Berdasarkan Status Gizi pada Siswi Remaja”, dapat kita simpulkan sebagai berikut.

a. Status gizi lebih, merupakan status gizi terbanyak yang ditemukan pada siswi remaja YPPS sebesar 41,17\%

b. Angka kejadian gangguan menstruasi dialami oleh 93 siswi $(91,17 \%)$ dari jumlah keseluruhan siswi 102 orang.

c. Gangguan menstruasi terbanyak dialami oleh remaja dengan status gizi lebih yaitu sebesar 44,08\% dari 93 siswi.

d. Jenis gangguan menstruasi terbanyak yang dialami oleh remaja berdasarkan tiga kategori status gizi adalah hipermenorea.

\section{Saran}

a. Institusi pendidikan dan kesehatan (pemerintah ataupun swasta) dapat melakukan kolaborasi dengan sekolahsekolah agar tercipta layanan terkait dengan kesehatan reproduksi remaja. Sehingga diharapkan dapat dilakukan upaya pencegahan ataupun penanganan dalam masalah tersebut, khususnya yang berkaitan dengan menstruasi dan status gizi remaja.

b. Siswi remaja diharapkan mampu berperan aktif dalam mengakses informasi kesehatan reproduksi remaja sesuai dengan usianya, terutama yang berkaitan dengan menstruasi dan status gizi remaja.

c. Terkat dengan keterbatasan dalam 
penelitian ini (hanya mengangkat variabel status gizi), diperlukan adanya penelitian lanjutan dengan melibatkan variabel etiologi gangguan menstruasi lain yang tidak di kaji dalam penelitian ini sehingga akan lebih membuka diskursus terkait penyebab dari setiap jenis gangguan menstruasi yang terjadi pada remaja.

\section{DAFTAR PUSTAKA}

Atikah Proverawati, E. K. W. (2010). Ilmu Gizi Untuk Keperawatan \& Gizi Kesehatan. Muha Medika

Badan Litbang Kesehatan, K. K. R. (2018). Laporan_Nasional_Rkd2018_Final.Pdf. In Badan Penelitian Dan Pengembangan Kesehatan (P. 198). Http://Labdata. Litbang.Kemkes.Go.Id/Images/ Download/Laporan/Rkd/2018/Laporan Nasional_Rkd2018_Final.Pdf

Batubara, J. R. (2016). Adolescent Development (Perkembangan Remaja). Sari Pediatri, 12(1), 21. Https://Doi.Org/10.14238/ Sp12.1.2010.21-9

Chung, P. W., Chan, S. S. C., Yiu, K. W., Lao, T. T. H., \& Chung, T. K. H. (2011). Menstrual Disorders In A Paediatric And Adolescent Gynaecology Clinic: Patient Presentations And Longitudinal Outcomes. Hong Kong Medical Journal, 17(5), 391-397.

Derina, K. A. (2011). Dengan Usia Menarche Pada Remaja Putri Di Smpn 155 Jakarta Tahun 2011.

Karout, N., Hawai, S. M., \& Altuwaijri, S. (2012). Prevalence And Pattern Of Menstrual Disorders Among Lebanese Nursing Students. Eastern Mediterranean Health Journal, 18(4), 346-352. Https://Doi. Org/10.26719/2012.18.4.346

Kementrian Kesehatan Ri. (2010). Riset
Kesehatan Dasar 2010. Badan Penelitian Dan Pengembangan Kesehatan, 78. Http://Www.Riskesdas.Litbang.Depkes. Go.Id/Download/Tabelriskesdas2010. Pdf

Łagowska, K., Jeszka, J., \& Bajerska, J. (2010). The Evaluation Of Nutritional Habits, Nutritional Status Triathlon's With And Without Menstrual Disorders. Medicina Sportiva, 14(4), 204-208. Https://Doi. Org/10.2478/V10036-010-0033-2

Larasati, T., \& Alatas, F. (2016). Dismenore Primer Dan Faktor Risiko Dismenore Primer Pada Remaja. Majority, 5(3), 7984.

Lubis, I. D., Tetap, D., Kedokteran, F., \& Medan, U. (2017). Jurnal Ilmiah Simantek Vol.1 No. 2 Juni 2017. 1(2), 165-170.

Mahitala, A. (2015). Hubungan Aktivitas Fisik Dengan Gangguan Menstruasi Wanita Pasangan Usia Subur Di Desa Temanggung Kecamatan Kaliangkrik Kabupaten Magelang Tahun 2015. Jurnal Kesehatan Masyarakat (E-Journal), 3(3), 74-80.

Milla, S., Mudayatiningsih, S., \& Dewi, N. (2018). Hubungan Obesitas Dengan Gangguan Menstruasi Pada Remaja Putri Di Kelurahan Tlogomas Solagrasia Yakoba Milla 1), Sri Mudayatiningsih 2), Novita Dewi 3) ${ }^{1}$ ). Nursing News : Jurnal Ilmiah Keperwatan, 3(1), 72-82.

Novia, I., Nunik Puspitasari, D., Kabupaten Sidoarjo, R., \& Biostatistika Dan Kependudukan Fakultas Kesehatan Masyarakat Universitas Airlangga, D. (N.D.). Faktor Risiko Yang Mempengaruhi Kejadian Dismenore Primer. Journal Unair.

Pusdatin. (2017). Infodatin Reproduksi RemajaEd.Pdf. In Situasi Kesehatan Reproduksi Remaja (P. 1). Https://Www.Kemkes. 
Go.Id/Download.Php?File=Download/ Pusdatin/Infodatin/Infodatin Reproduksi Remaja-Ed.Pdf

Rad, M., Torkmannejad Sabzevary, M., \& Mohebbi Dehnavi, Z. (2018). Association Between Menstrual Disorders And Obesity-Related Anthropometric Indices In Female High School Students: A Cross-Sectional Study. International Journal Of School Health, 5(2). Https:// Doi.Org/10.5812/Intjsh.65716

Sari, A. F. I., Briawan, D., \& Dwiriani, C. M. (2016). Kebiasaan Dan Kualitas Sarapan Pada Siswi Remaja Di Kabupaten Bogor. Jurnal Gizi Dan Pangan, 7(2), 97. Https:// Doi.Org/10.25182/Jgp.2012.7.2.97-102
Sianipar, O., Bunawan, N. C., Almazini, P., Calista, N., Wulandari, P., Rovenska, N., Djuanda, R. E., Irene, Seno, A., \& Suarthana, E. (2009). Prevalensi Gangguan Menstruasi Dan FaktorFaktor Yang Berhubungan Pada Siswi Smu Di Kecamatan Pulo Gadung Jakarta Timur. Maj Kedokt Indon, 59(7), 308-313. Http://Www.Academia.Edu/ Download/44385535/653-707-1-Pb.Pdf

Yusiana, M. A., Silvianita, M., Saputri, T., \& Kediri, S. R. B. (N.D.). Perilaku Personal Hygiene Remaja Puteri Pada Saat Menstruasi Perilaku Personal Hygiene Remaja Puteri Pada Saat Menstruasi Personal Hygiene Behavior Female Teenager When To Menstruating. 14-19. 